\title{
SOME GEOMETRIC PROPERTIES OF MUSIELAK-ORLICZ SEQUENCE SPACES GENERATED BY DE LA VALLÉE-POUSSIN MEANS
}

\author{
Atanu Manna And P. D. SRivastava
}

Abstract. Necessary and sufficient conditions for the non-triviality of a Musielak-Orlicz sequence space $V_{\Phi}(\lambda)$ generated by the de la Vallée-Poussin means are obtained. Topological properties such as completeness, separability, order continuity are characterized for the space $V_{\Phi}(\lambda)$. Finally, criteria for the coordinatewise uniformly Kadec-Klee property and the Uniform Opial property are obtained.

Mathematics subject classification (2010): 46B20, 46B25, 46B40, 46B45, 46A45, 46A80.

Keywords and phrases: Musielak-Orlicz function, de la Vallée-Poussin means, Amemiya norm, Luxemberg norm, Fatou property, order continuity, coordinatewise Kadec-Klee property, uniform Opial property.

\section{REFERENCES}

[1] A. KAMińSKa, Uniform rotundity of Musielak-Orlicz sequence spaces, Journal of Approximation Theory, 47, 4 (1986), 302-322.

[2] H. HudziK, Y. N. Ye, Support functionals and smoothness in Musielak-Orlicz sequence spaces endowed with Luxemberg norm, Comment. Math. Univ. Carolinae, 31, 4 (1990), 661-684.

[3] J. MusielaK, Orlicz spaces and Modular spaces, Springer Lecture notes in Math., 1034, Springer, 1983.

[4] J. P. Gossez, E. Lami Dozo, Some geometric properties related to fixed point theory for non expansive mappings, Pacific Journal of Math., 40, (1972), 565-573.

[5] L. LEINDLER, Über die verallgemeinerte de la Vallée-Poussinsche Summierbarkeit allgemeiner Orthogonalreihen, Acta Math. Acad. Sci. Hungar., 16, (1965), 375-387.

[6] L. V. Kantorovich, G. P. Akilov, Functional Analysis, Pergamon Press and "Nauka", Second Edition, 1982.

[7] M. I. KADETS, The relation between some properties of convexity of the unit ball of a Banach space, Functional Analysis and Its Application, 16, 3 (1982), 204-206 (translation).

[8] M. Murs aleen, $\lambda$-statistical convergence, Math. Slovaca, 50, 1 (2000), 111-115.

[9] N. Petrot, S. Suantai, Some geometric properties in Cesàro-Orlicz Spaces, Science Asia, 31, (2005), 173-177.

[10] N. Petrot, S. SuAntaI, Uniform Opial properties in generalized Cesàro sequence spaces, Nonlinear Analysis, 63, (2005), 1116-1125.

[11] N. ŞIMŞEK, E. SAVAŞ, V. KARAKAYA, Some geometric and topological properties of a new sequence spaces defined by De La Vallée-Poussin Mean, Journal of Computational Analysis and Applications, 12, 4 (2010), 768-779.

[12] N. ŞIMŞEK, On some geometric of sequence space defined by De La Vallée-Poussin Mean, Journal of Computational Analysis and Applications, 13, 3 (2011), 565-573.

[13] P. For Alewski, H. Hudzik AND A. Szymaszkiewicz, Some remarks on Cesàro-Orlicz spaces, Mathematical Inequalities and Applications, 13, 2 (2010), 363-386.

[14] P. Foralewski, H. Hudzik, On some geometrical and topological properties of generalized Calderón-Lozanovski $\breve{i}$ sequence spaces, Houston Journal of Mathematics, 25, 3 (1999), 523-542.

[15] P. Foralewski, H. Hudzik, A. Szymaszkiewicz, Local rotundity structure of Cesàro-Orlicz sequence spaces, J. Math. Anal. Appl., 345, 1 (2008), 410-419. 
[16] R. HufF, Banach spaces which are nearly uniformly convex, Rockey Mountain J. Math., 10, (1980), $743-749$.

[17] R. WAngKeEree, On property $(k-N U C)$ in Cesàro-Musielak-Orlicz sequence spaces, Thai Journal of Mathematics, 1, (2003), 119-130.

[18] S. T. Chen, Geometry of Orlicz spaces, Dissertationes Math., 356, (1996), 1-204.

[19] S. Prus (EDS. W. A. KIRK AND B. SiMS), Geometrical background of metric fixed point theory, Handbook of Metric Fixed Point Theory, Kluwer Academic Publishers, Dordrecht, 2001, 93-132.

[20] S. PRUS, Banach spaces with Uniform Opial property, Nonlinear Anal. Theory Appl., 18, 8 (1992), 697-704.

[21] T. Zhang, The coordinatewise Uniformly Kadec-Klee property in some Banach spaces, Siberian Mathematical Journal, 44, 2 (2003), 363-365.

[22] W. A. J. LuXEMBuRG, Banach function spaces, Thesis, Delft, (1955).

[23] Y. Cui, H. Hudzik, N. Petrot, S. Suantai And A. Szymaszkiewicz, Basic topological and geometric properties of Cesàro-Orlicz spaces, Proc. Indian Acad. Sci. (Math. Sci.), 115, 4 (2005), 461-476.

[24] Y. CUI, H. HudzIK, Maluta's coefficient and Opial's properties in Musielak-Orlicz sequence spaces equipped with the Luxemberg norm, Nonlinear Analysis, 35, (1999), 475-485.

[25] Y. CUI, H. HUdZIK, On the Uniform Opial property in some modular sequence spaces, Func. Approx. Comment., 26, (1998), 93-102.

[26] Z. OPIAL, Weak convergence of the sequence of successive approximations for non expansive mappings, Bull. Amer. Math. Soc., 73, (1967), 591-597. 